\title{
THE EFFECTIVENESS AND CONTRIBUTION OF ADVERTISEMENT TAX TO INCREASE THE ORIGINAL REVENUE OF MATARAM CITY
}

\author{
Nia Kurniati \\ Department of Public Administration, Sekolah Tinggi Ilmu Administrasi Mataram \\ Email: niaalqiya@gmail.com
}

\begin{abstract}
This study aims to determine the effectiveness and contribution of advertisement tax revenue to increase the realization of Mataram City's Local Revenue, and to find out the obstacles faced in regulating advertisement taxpayers and the efforts made to increase advertisement tax revenue. The type of research used is qualitative research. The type of data used is primary data and secondary data. The analytical tool used is the effectiveness ratio, contribution ratio, and descriptive analysis. The research model used is the Miles and Huberman model, which consists of data reduction, data presentation, and conclusion drawing. The results showed that 2013, 2015 and 2016 the effectiveness of advertisement tax revenue was in the very effective category. As for 2014 and 2017 are in the less effective category. So that if averaged the value of effectiveness is $99.82 \%$ with the effective category. The advertisement tax contribution to the PAD is still very less because it is still in a position below 10\%.

Keywords: advertisement tax, effectiveness, contribution, taxpayer
\end{abstract}

\section{INTRODUCTION}

The increase in population and development that must continue and be sustainable requires the Government to be able to obtain a very strategic source of income to help increase the State's revenues. Tax is one of the potential alternatives because the income from the tax sector is relatively stable and also as a form of participation of the
Indonesian people in supporting the development and programs of the Government.

Under the laws of the Republic of Indonesia e.g. 23 Year 2014 about local governance, the Central Government gives full authority to local governments in managing his real. Under the laws of 
the Republic of Indonesia e.g.33 Year 2004 of Financial Equalization between the central government and local governments, in chapter I article 118 grains mentioned that the original Income are as here in after referred to as the PAD is the income the Area gained admission on the basis of the regulatory area in accordance with legislation.

The municipality of Mataram is one of the autonomous region was established on the basis of Act e.g. 4 of the year 1993 on the establishment of the municipality of regencies of Mataram. In the implementation of the autonomous region, the local Government of the city of Mataram can be expected to dig into the potential that exists on the area of its authority in order to increase the $\mathrm{PAD}$, so the dependence will help the Central Government and lending could be reduced.

The independence of a region can be seen from the ratio of regional financial independence, the higher value of the ratio financial independence then this means that dependence against central Government and loans on the wane. One of the sources of the expected tax areas can increase PAD of the Mataram City is through Advertisement Tax. Advertisement is the media, tools, objects and acts according to the shape and pattern of manifold is used for commercial purposes such as to introduce, encourage, an item or person. Advertising is necessary for everyone, this is because everyone needs inform. Many employers also want to market their products of billboards, even for personal ads, as well as at campaign time.

In 2013, 2015 and 2016 the realization of advertising tax Mataram city already exceeding the target which has been set. In the year 2014 and 2017, the realization of the advertising tax has not been the fullest. The following data development targets and the realization of advertising tax Mataram City on the table 1: 
Table 1 Data Development Targets and Realization Of Advertising Tax Mataram Year 2013 - 2017

\begin{tabular}{|c|c|c|c|}
\hline No & Year & Targets (Rp) & $\begin{array}{c}\text { Realization } \\
\text { (Rp) }\end{array}$ \\
\hline 1. & 2013 & 1.800 .000 .000 & 2.503 .552 .597 \\
\hline 2. & 2014 & 1.900 .000 .000 & 1.375 .745 .077 \\
\hline 3. & 2015 & 2.250 .000 .000 & 2.597 .700 .380 \\
\hline 4. & 2016 & 2.500 .000 .000 & 2.761 .600 .947 \\
\hline 5. & 2017 & 4.000 .000 .000 & 2.467 .694 .745 \\
\hline
\end{tabular}

Source: Regional Financial Entity Of Mataram City

From table 1 is visible that the local Government of Mataram city of the financial Entity in this area (BKD) as implementer haven't been able to get the value of an advertising tax already targeted. This must be a big question on be half of $\mathrm{BKD}$, and the general public related to the constraints faced in regulating taxpayer of advertise. Although there are some obstacles faced related to tax revenues this advertisement, Billboard obtained tax value per year is still able to give its contribution to the increase in mataram city PAD though. The purpose of this study is:
1. To determine the level of effectiveness of advertisement tax revenue in increasing the Regional Original Revenue of Mataram City.

2. To find out the contribution of advertisement tax revenue to increase the Regional Original Revenue of Mataram City.

3. To find out the obstacles faced in advertisement tax collection in Mataram City.

4. To find out the efforts to increase regional income through advertisement tax.

Effectiveness and Contribution of Advertising Tax Revenue

The definition of effectiveness is the balance between actual income (tax and retribution) on potential income from a tax that is assuming that those who should pay the amount that should be paid actually fulfill their obligations.

\section{RESEARCH METHODS}

The type of research used in this study is a type of qualitative research. The type of data used in this study is 
secondary data and primary data. Primary data collection techniques were obtained from interviews conducted by researchers with resource persons were the Head of the regional tax division and the BKD staff of Mataram City, the management section was related to the Government's constraints and efforts to increase advertisement tax revenue.

The secondary data comes from collecting literature and data documents on the development of targets and realization of Mataram City's Original Revenue in 2013-2017. Data analysis using the Miles and Huberman models consisting of data painting, data presentation, and conclusion drawing.

Based on the data obtained, then it can calculate the level of effectiveness from advertisement tax and its contribution to PAD. The level of effectiveness is used to find out how far the achievement of the realization of advertisement tax revenue towards the advertisement tax revenue target that has been set by the local government.
The level of effectiveness can be formulated as follows:

$\frac{\text { realization of advertisement tax revenue }}{\text { advertisement tax revenue target }} \times 100 \%$

Table 2 Classification Criteria of Effectiveness

\begin{tabular}{|l|l|}
\hline \multicolumn{1}{|c|}{ The Percentage } & \multicolumn{1}{c|}{ Criteria } \\
\hline$>100 \%$ & Very Effective \\
\hline $91 \%-100 \%$ & Effective \\
\hline $81 \%-90 \%$ & Quite Effective \\
\hline $61 \%-80 \%$ & Less Effective \\
\hline$<60 \%$ & Not Effective \\
\hline
\end{tabular}

Source: Regional Financial Entity Profiles of Mataram City

$$
\text { Contributions are used to }
$$

determine the extent to which local taxes, especially advertisement taxes, contribute to the receipt of PAD. In knowing the contribution is done by comparing the local tax revenue (especially advertisement tax) for a certain period with a certain period of $\mathrm{PAD}$ revenue. The greater the result means the greater the role of local taxes on $\mathrm{PAD}$, and vice versa if the results of the comparison are too small, the role of local taxes on PAD is also small. Advertising tax contributions can be calculated using the formula: 
realization of advertisment tax revenue

PAD realization

Table 3 Classification Criteria Of Contribution

\begin{tabular}{|l|l|}
\hline \multicolumn{1}{|c|}{ The Percentage } & \multicolumn{1}{c|}{ Criteria } \\
\hline $0,00 \%-10 \%$ & Very Less \\
\hline $10,10 \%-20 \%$ & Less \\
\hline $20,10 \%-30 \%$ & Is Being \\
\hline $30,10 \%-40 \%$ & Good Enough \\
\hline $40,10 \%-50 \%$ & Good \\
\hline$>50 \%$ & Very Good \\
\hline
\end{tabular}

Source: Regional Financial Entity Profiles of Mataram City

\section{RESULT AND DISCUSSIONS}

The Effectiveness of Advertisement Tax Revenue in Mataram City

The calculation of effectiveness is used to see how far the achievement of the realization of advertisement tax revenue against the advertisement tax target has been set by the Mataram City Government. From the data of the target development report and the realization of the advertisement tax of Mataram City obtained from the Regional Finance Agency of the City of Mataram, the results of the calculation of the advertisement tax effectiveness analysis of Mataram City can be seen in the following table:
Table 4 Analysis of the effectiveness of the advertising tax revenue the city of Mataram $2013-2017$

\begin{tabular}{|c|c|c|c|c|}
\hline \multirow[b]{2}{*}{ Year } & \multicolumn{2}{|c|}{ Advertisemet Tax } & \multirow{2}{*}{$\begin{array}{l}\text { The } \\
\text { Effectiveness of } \\
\text { advertising tax } \\
\text { revenue }\end{array}$} & \multirow[b]{2}{*}{ Criteria } \\
\hline & Targets (Rp) & $\begin{array}{c}\text { Realization } \\
\text { (Rp) }\end{array}$ & & \\
\hline 2013 & 1.800 .000 .000 & 2.503.552.597 & $139,09 \%$ & $\begin{array}{l}\text { Very } \\
\text { Effective }\end{array}$ \\
\hline 2014 & 1.900 .000 .000 & 1.375 .745 .077 & $72,41 \%$ & $\begin{array}{l}\text { Less } \\
\text { Effective }\end{array}$ \\
\hline 2015 & 2.250 .000 .000 & 2.597 .700 .380 & $115,45 \%$ & $\begin{array}{l}\text { Very } \\
\text { Effective }\end{array}$ \\
\hline 2016 & 2.500 .000 .000 & 2.761 .600 .946 & $110,46 \%$ & $\begin{array}{l}\text { Very } \\
\text { Effective }\end{array}$ \\
\hline 2017 & 4.000 .000 .000 & 2.467.694.745 & $61,69 \%$ & $\begin{array}{l}\text { Less } \\
\text { Effective }\end{array}$ \\
\hline
\end{tabular}

Source: Regional Financial Entity of Mataram City, Processed Data

Based on Table 4, it can be seen that in 2013, the effectiveness of advertisement tax revenue was $139.09 \%$ and was in a very effective category. This is because the value of advertisement tax that has been targeted by the City Government of Mataram in 2013 can be smoothly realized, even the realization far exceeds what has been targeted. Similar to 2015, the effectiveness value was $115.45 \%$ and in 2016 the effectiveness value was $110.46 \%$ so that in 2015 and 2016 it was also in the very effective category because in that year the advertisement 
tax value targeted to be realized far exceeded the target.

In 2014, the effectiveness of advertisement tax revenue was $72.41 \%$ and was in the less effective category. This is due to the transition period of advertisement tax management. Where previously, this advertisement tax management was authorized to the Mataram City Parks Service, which is now changed to the Department of Settlements and Urban Areas (Perkim) of Mataram City, both from permits, taxes, and regulations, and then the authority was given to the Mataram City Regional Finance Agency to manage tax. While the management of the permit is given authority to the Integrated Service Investment Office One Door of Mataram City. In order to control and supervise the billboards, authority was given to the Mataram District Office of Regulations.

In 2017, the effectiveness of advertisement tax revenue was $61.60 \%$ and was in a less effective category. This is because, in addition to the very large target set by the Local
Government of Mataram City when compared to the previous year's targets, many taxpayers do not take care of permits, either new installation permits or extension of advertisement permits. As a result, many billboards were installed without using permits, which caused the Government in this case represented by the Mataram City Settlement and Public Housing Agency to carry out control. Where, in this control, of course, it will cost a lot of money. However, if the average value of effectiveness from 2013-2017 is $99.82 \%$, this means that it is in the effective category.

\section{The Contribution of Advertising Tax Revenue in Mataram City}

From the data of the target development report and the realization of the PAD of Mataram City obtained from the Regional Finance Agency of Mataram City, the results of calculations related to the analysis of the advertisement tax contribution of Mataram City can be seen in the following table. 
Table 5 Analysis of The

\section{Contribution Of The Advertising}

Tax Revenue The City Of Mataram

2013 - 2017

\begin{tabular}{|c|c|c|c|c|}
\hline Year & $\begin{array}{c}\text { Realization } \\
\text { of } \\
\text { advertisemen } \\
\text { t tax (Rp) }\end{array}$ & $\begin{array}{c}\text { Realization of } \\
\text { PAD (Rp) }\end{array}$ & Contribution & Criteria \\
\hline 2013 & 2.503 .552 .597 & $134.411 .455 .232,00$ & $1,86 \%$ & $\begin{array}{l}\text { Very } \\
\text { Low }\end{array}$ \\
\hline 2014 & 1.375 .745 .077 & $202.589 .009 .699,00$ & $0,68 \%$ & $\begin{array}{l}\text { Very } \\
\text { Low }\end{array}$ \\
\hline 2015 & 2.597 .700 .380 & $222.578 .368 .328,00$ & $1,18 \%$ & $\begin{array}{l}\text { Very } \\
\text { Low }\end{array}$ \\
\hline 2016 & 2.761 .600 .946 & $288.096 .362 .727,00$ & $0,96 \%$ & $\begin{array}{l}\text { Very } \\
\text { Low }\end{array}$ \\
\hline 2017 & 2.467 .694 .745 & $377.124 .304 .044,59$ & $0,65 \%$ & $\begin{array}{l}\text { Very } \\
\text { Low }\end{array}$ \\
\hline
\end{tabular}

Source: Regional Financial Entity of Mataram City, Processed Data

Based on Table 5, it can be seen that the contribution of advertisement tax to the PAD is still very lowbecause it is still in a position below $10 \%$. This is because there are still many taxpayers who do not take care of licensing issues, either for new ones or for extensions. The number of billboards without this permit, of course, the Government must control, which in this order will result in expenditure. In addition, the lack of advertisement tax contribution to the PAD of Mataram City was due to a reduction in the installation of several advertisements, such as cigarette advertising. Instead of eliminating this cigarette advertisement altogether, it will reduce the broadcast period, for example from the period of 1 (one) month to 1 (one) week, of course, this will reduce the tax value. Besides that, regulating the distance of cigarette advertisement installation from the school environment, of course, this has an impact that the location of the installation is in an area that is less potential (less strategic).

Advertisement tax revenue in the city of Mataram during the period 2013 - 2017 can be said to be less than optimal in certain years, namely in 2014 and 2017, where the value of advertisement tax that has been targeted cannot be realized properly. While in 2013, 2015 and 2017 can be realized well, because the value of the advertisement tax obtained exceeds the target set. Unlike the case with the original regional income (PAD) of Mataram City which can always be realized well during the 2013-2017 period, this is because the sources of 
PAD in Mataram City are not only from advertisement taxes which are part of local taxes, but there are still sources of PAD others such as regional levies, the results of the management of separated regional assets, and others PAD separated. PAD Mataram City from 2013 to 2017 continues to increase.

\section{Constraints Faced in Collecting} Advertisement Tax in Mataram City

From the analysis of the effectiveness and contribution of advertisement tax revenue to the increase in the PAD of Mataram City, moreover in the contribution analysis which in the period of this study using data from 2013 - 2017 was still in the very poor category. While the effectiveness analysis is only seen in 2014 and 2017 which are in the less effective category. From the results of these calculations, of course, there are several obstacles faced in the advertisement tax collection in the city of Mataram, so that it still has not provided a good contribution to the increase in the PAD of Mataram City. The constraints faced in the advertisement tax collection in the city of Mataram, so it still has not provided a good contribution to the improvement of the Mataram City PAD, including:

1. A taxpayer who does not take care of the permit to install an advertisement (advertisement without permission).

2. Many taxpayers pay advertisement tax payments, related to the extension license. In this case, also, the taxpayer if the reclamation period has expired, sometimes does not carry out self-control, but allowing the advertisement to remain aired on the pretext if the Government conducts curbing it will definitely be stopped and if it has not taken control, the billboard will still be aired.

3. The number of taxpayers, in the case of the installation of billboards, prefers areas that are less potential (less strategic locations). Where the determination of the installation of this location will also result in the tax value. 
Efforts Made in Increasing Advertising Tax Revenue in Mataram City

Efforts were made by the Mataram City Government to increase advertisement tax revenue in the City of Mataram, including:

1. Payment of taxes must be made at once (in full), the due date of payment and deposit of tax payable 15 (fifteen) days after the time the tax is due. Installments of tax payments payable are regularly made and are subject to a fine of $2 \%$ per month from the amount of tax that has not been paid or underpaid.

2. Providing social sanctions to the billboard tax arrears, which will begin in 2018. Where on the taxpayer billboard will be written "This advertisement has no tax" or "This advertisement has no permission". This is to discipline taxpayers in paying taxes. In addition, the community can assess and see directly the unpaid billboards or manage their permits. In addition, in the future, it is expected that taxpayers will be disciplined regarding the reclamation period and can carry out their own control of the reclamation so that the Government in this case represented by the Department of Public Works of Mataram City no longer needs to control or reduce the costs of enforcement.

3. Providing convenience in handling advertisement permits and maximizing strategic locations in the installation of billboards. Regarding this advertisement permit, the Government advised taxpayers to complete the documents, even the Government also conducted socialization one way by putting up billboards and advertisements in some areas of Mataram City, that managing permits was easy, and always displaying advertisements "STOP PUNGLI ".

\section{CONCLUSIONS}

The effectiveness of advertisement tax receipt in Mataram City from 2013 to 2017, if taken on 
average is in the effective category, with an average value of $99.82 \%$. The advertisement tax contribution of the City of Mataram in 2013 - 2017 was stated to be very lacking in contributing to the PAD, it can be seen from the criteria that the contribution made was in a position below $10 \%$.

The constraints faced in the advertisement tax collection in the city of Mataram are taxpayers who do not take care of the installation of billboards (billboards without permission), many taxpayers pay advertisement tax payments, related to the extension permit, less awareness of the taxpayer to control itself against billboards that have expired, the number of taxpayers prefers areas that are less potential (less strategic locations) in the installation of billboards.

The efforts made by the Government to increase advertisement tax revenue in the City of Mataram are advertisement taxes that delay payments will be subject to a fine of $2 \%$ per month from the amount of tax that has not been paid or owed, giving social sanctions to the billboard tax arrears such as writing a message on the advertisement This has no tax yet "or" This advertisement does not have a permit and provides convenience to taxpayers in handling advertisement installation permits.

To be able to increase advertisement tax revenue, the regional government is expected to open access to 1 (one) door in handling permits and paying advertisement taxes, which during this time in handling taxpayer permits do so in the Integrated Services Investment Service One Door (DPMPTSP) of Mataram City, while in paying taxes, taxpayers must go to the BKD office. Things like this make the community in general or billboard taxpayers, in particular, feel that the bureaucracy is rather hampering in administering administration.

BKD Mataram City continues to coordinate with DPMPTSP to take care of advertisement tax permits by holding out socialization to the community related to the management 
of this tax, because many people still think that arranging advertisement permits and taxes is still the authority of the Mataram City Parks Service which is now converted into the Settlement Service and Urban Mataram City. While the distance from the BKD office, DPMPTSP with the Mataram District Office of Religion was relatively far away.

\section{REFERENCES}

Atteng, Jovanly. Saerang, David. Mawikere, Lidya. 2016. Analisis Efektivitas dan Kontribusi Pajak Reklame Terhadap Pendapatan Asli Daerah (PAD) di Kota Manado Tahun 2011 - 2015 Studi Kasus Pada Dinas Pendapatan Daerah Kota Manado. Jurnal Berkala Ilmiah Efisisensi Volume 16 No. 04.

Badan Keuangan Daerah Kota Mataram. 2017. Profil Badan Keuangan Daerah Kota Mataram. Mataram.

Ikatan Akuntan Indonesia. 2015. Modul Pelatihan Pajak Terapan Brevet AB Terpadu. Jakarta

Mahmudi. 2010. Manajemen Keuangan Daerah. Jakarta: Erlangga

Rahman, Khuzain. 2017. Pengaruh Pemungutan Pajak Reklame Terhadap Pendapatan Asli Daerah (PAD) Ditinjau Dalam
Perspektif Ekonomi Islam (Studi Kasus Di Kota Bandar lampung Tahun 2010 - 2015). Raden Intan Repository.

Rinawati, Reny. 2013. Analisis Pengaruh Pemungutan Pajak Reklame Terhadap Upaya Peningkatan Pendapatan Asli Daerah (PAD) Kota Surabaya. Jurnal Akuntansi Unesa Volume 1. No. 2.

Siahaan, Marihot Pahala. 2010. Pajak Daerah dan Retribusi Daerah. Jakarta: Raja Grafindo Persada.

Sugiyono. 2014. Metode Penelitian Kuantitatif Kualitatif dan R\&D. Bandung: Alfabeta

Sugiyono. 2014. Memahami Penelitian Kualitatif. Bandung: Jakarta.

Waluyo. 2008. Perpajakan Indonesia. Edisi Kedelapan. Buku Satu. Jakarta: Salemba Empat.

Waluyo. 2011. Pajak di Indonesia. Jakarta: Salemba Empat.

Widowati, Santhya. 2014. Analisis

Kontribusi Pajak Reklame Dalam

Meningkatkan Pendapatan Asli Daerah Di Kabupaten Sidoarjo Tahun 2011 - 2013. Jurnal Akuntansi Unesa Volume 3 No. 1.

Undang-Undang Republik Indonesia Nomor 23 Tahun 2014 Tentang Pemerintahan Daerah. Lembaran Negara Republik Indonesia Tahun 2014 Nomor 244.

Undang-Undang Republik Indonesia Nomor 33 Tahun 2004 Tentang Perimbangan Keuangan Antara Pemerintah Pusat dan Pemerintah Daerah. Lembaran Negara 
The Effectiveness and Contribution of Advertisement Tax ......... (Nia Kurniati)

Republik Indonesia Tahun 2004 Nomor 126.

Undang-Undang Republik Indonesia Nomor 4 Tahun 1993 Tentang Pembentukan Kotamadya Daerah Tingkat II Mataram. Lembaran Negara Republik Indonesia Tahun Nomor 3531.

Undang-Undang Republik Indonesia

Nomor 28 Tahun 2009 Tentang

Pajak Daerah dan Retribusi
Daerah. Lembaran Negara Republik Indonesia Tahun 2009 Nomor 130.

Peraturan Daerah Kota Mataram Nomor 7 Tahun 2010 Tentang Reklame.

Peraturan Daerah Kota Mataram Nomor 1 Tahun 2014 Tentang Penyelenggaraan Pajak Reklame. 28 Februari 2014. 